\title{
KRITERIJI ZA IZRICANJE ODGOJNIH MJERA
}

Prof. dr. sc. Ljiljana Mikšaj - Todorović*

Maja Vučić Blažić, prof. paed. soc.**

\author{
UDK: 343.915 \\ https://doi.org/10.30925/zpfsr.41.2.1 \\ Ur.: 23. svibnja 2020. \\ Pr.: 29. lipnja 2020. \\ Izvorni znanstveni rad
}

\begin{abstract}
Sažetak
U radu se polazi od suvremene filozofije tretmana mladih počinitelja kaznenih djela koja se temelji na spoznaji da je najprimjerenija i najučinkovitija intervencija ona koja se oslanja na njihove specifične potrebe i potencijale. Da bi sud za maloljetnike mogao donijeti najbolju odluku o odgojnoj mjeri, potrebni su mu relevantni podatci. U radu su analizirana izvješća centara za socijalnu skrb u smislu njihove informativnosti, te preklapanje prijedloga odgojnih mjera stranaka u postupku s odlukama suda. Prema očekivanju, izvješća su nestrukturirana, neujednačena i nepotpuna. Od 149 očekivanih podataka, sudovima je prosječno dostavljena tek četvrtina. Usprkos tomu, preklapanja prijedloga odgojnih mjera različitih dionika s odlukama suda vrlo su visoka. Svrha je ovoga rada, nakon istraživačkim postupkom utvrđene i opravdano očekivane (ne)adekvatnosti u procesu prikupljanja podataka kao i podataka potrebnih sudovima, ponuditi održivi model koji će rezultirati kvalitetnim prikupljenim podatcima. Model je opisan u radu.
\end{abstract}

Ključne riječi: maloljetnici; kaznena djela; kriteriji; odgojne mjere; izvješća.

\section{1. $U V O D$}

Pitanje kvalitete podataka koji su sudovima za mladež potrebni kako bi donijeli najbolju odluku pri izricanju odgojne mjere otvoreno je i u hrvatskoj i u svjetskoj literaturi i praksi. Dok je u nekim zemljama postupak prikupljanja i interpretacije takvih podataka visoko standardiziran, ${ }^{1} \mathrm{u}$ nekima postoje vodiči za te procedure kao preporučeni ili obvezni materijal ${ }^{2}$ ili prijedlozi standardizacija različitim

* Dr. sc. Ljiljana Mikšaj - Todorović, redovita profesorica u trajnom zvanju, Edukacijskorehabilitacijski fakultet Sveučilišta u Zagrebu, Odsjek za kriminologiju; ljiljana.miksajtodorovic@erf.hr.

** Maja Vučić Blažić, profesorica socijalni pedagog, Centar za pružanje usluga u zajednici Zagreb-Dugave; vucicblazicmaja@gmail.com.

1 Masaru Takahashi, „Assessment of Juvenile offenders at juvenile Classification Homes in Japan. United nations Asia and Far east Institute for the Prevention of Crime and the Treatment of Offenders (UNAFEI)"Resource material, 78, (2009): 151-158.

2 Ashley Mears, „Aesthetic Labor for the Sociologies of Work“, Gender, and Beauty, Sociology 
instrumentima. ${ }^{3}$ U Republici Hrvatskoj to je područje već dulje vrijeme prilično zanemareno. ${ }^{4}$ Tim pitanjem bavi se ovaj rad.

Svrha je rada, nakon istraživačkim postupkom utvrđene (ne)adekvatnosti u procesu prikupljanja navedenih podataka kao i samih podataka, ponuditi održivi model koji će rezultirati kvalitetnim prikupljenim podatcima. Područje kvalitete podataka koji su sudu potrebni je sine qua non daljnjeg postupka i tek nakon njegova sustavnog uređenja može se ići korak dalje, što bi značilo edukaciju svih dionika u procesu odlučivanja kao i reforme ustanova za izvršavanje odgojnih mjera. Prikupljena dokumentacija svakako je potrebna i tim ustanovama kako bi se moglo individualizirati izvršenje odgojnih mjera. Spomenuta očekivana (ne)adekvatnost proizlazi iz brojnih radova domaćih autora na koje se ovaj rad poziva.

$\mathrm{Za}$ razliku od slučajeva u kojima su počinitelji kaznenih djela punoljetne osobe (iako i ovdje ima primjedbi), ${ }^{5}$ sud će pri izricanju odgojnih mjera biti znatno precizniji u procjeni odnosa težine kaznenog djela, determinanti takvog ponašanja te pokazatelja za tretman koji slijedi. Sve se procedure temelje na najboljem interesu djeteta i formulacije opisane u hrvatskom zakonodavstvu ${ }^{6}$ vezane uz svrhe izricanja sankcija, slične su onima u mnogim drugim zemljama. ${ }^{7}$

Republika Hrvatska u tom smislu pripada, tzv. umjerenim sustavima. Naime, povijesno, u svijetu se mogu prepoznati glavne faze razvoja teorijskih podloga $\mathrm{i}$ sukladno tome, promjena u praksi maloljetničkog sudovanja u smislu izricanja najboljih mjera/sankcija. Tako u podlozi doktrine parens patriae ${ }^{8}$ stoji tumačenja da su, zbog mladosti, za ponašanje djece odgovorni roditelji, a potom je obveza države

Compass 8, br. 12 (2014): 1330-1343; Gina M. Vincent, Laura S. Guy i Thomas Grisso, Risk Assessment in Juvenile Justice: A Guidebook for Implementation. Models for Change-systems Reform in Juvenile Justice. MacArthur Fondation. University of Massachusets, 2012.

3 Evert M. Scholte, „Psychosocial Risk Characteristics of Children in Welfare programmes in Holland“, Childhood: A Global Journal of Child Research 5, br. 2 (1998): 185-205.

4 Mladen Singer, Konstantin Momirović i Vojislav Kovačević, „Kriteriji sudova pri izricanju sankcija maloljetnicima“, Defektologija 12, br. 1-2 (1976): 48-121; Dalida Rittossa i Melita Božićević Grbić, „Zakon o sudovima za mladež - reformski zahvati i praktične dileme“, Hrvatski ljetopis za kazneno pravo i praksu 19, br. 2 (2012): 615-667.

5 Više u: Velinka Grozdanić, Zoran Sršen i Dalida Rittossa, „Kaznena politika općinskih sudova na području Županijskog suda u Rijeci“, Hrvatski ljetopis za kazneno pravo i praksu 11, br. 2 (2004): 567-608.

6 Prema Zakonu o sudovima za mladež, svrha je odgojnih mjera propisana čl. 6 .

7 Vidi: Daniel Mears, „Sentencing Guidelines and the Transformation of Juvenile Justice in the 21st Century“, Journal of Contemporary Justice 18, br. 1 (2002): 6-19; New Jersey Code, Purposes, 2009., pristup 16. siječnja 2020., https://law.justia.com/codes/new-jersey/2009/ title-2a/2a-4a-21; Jean Zermatten, „The best Interests of the Child. Literal Analysis, Function and Implementation, Institut International des Droits de lenfant“. „,Working Report,, 2009. Vidi i: Frieder Dunkel, „Juvenile Justice Systems in Europe - reform developments between justice, welfare and »new punitivness“, Kriminologijos studios, br. 1 (2014), 10.15388/ CrimLithuan.2014.0.3676.

8 Margaret Hall, „The Vulnerability Jurisdiction: Equity, parens patriae, and the Inherent Jurisdiction of the Court", Canadian Journal of Comparative and Contemporary Law 2, br. 1 (2016): 186-225. 
da intervenira u život djeteta čiji mu roditelji ne pružaju odgovarajuću brigu i skrb. ${ }^{9}$ Potom dolazi do transformacije u, tzv. umjerene sustave maloljetničkog sudovanja pri čemu se kombinira utjecaj različitih čimbenika na maloljetnu osobu, ali se sve više računa i na njezinu odgovornost i kapacitete za promjenom ponašanja. Pri tom se poseže za najmanjim, ali što ranijim i hitnijim intervencijama u odgoj i obrazovanje, za proširenjem diskrecijskog prava policije i odvjetništva u odlučivanju u svrhu primjene neformalnih mjera i rasterećenja sudova ${ }^{10}$ te za razgranatim mogućnostima interveniranja drugih sustava, ponajprije sustava socijalne skrbi u cilju što manjeg izdvajanja iz obitelji. I napokon, mogu se prepoznati nove, tzv. neoliberalne tendencije koje svoje opravdanje u pojedinim zemljama vide u mnogim društvenim čimbenicima današnjice. ${ }^{11}$

Dunkel $^{12}$ procjenjuje da nema naznaka da bi kontinentalne europske zemlje ili velika većina njih, regredirale prema klasicizmu odnosno penalnom populizmu kako se danas naziva u literaturi. ${ }^{13}$ One se i dalje temelje na načelima odgoja i obrazovanja odnosno specijalne prevencije iako ostaje otvoreno pitanje ravnoteže između takvog pristupa i onoga drugog, kažnjavajućeg. U tom smislu, uvelike mogu pomoći brojni međunarodni dokumenti. ${ }^{14}$

Deklaracije i pravila praćena su nizom vodiča, preporuka i smjernica koje državama olakšavaju unaprjeđenje zakonodavstva i prakse.

Suvremena filozofija cjelokupnoga tretmana mladih počinitelja kaznenih djela temelji se na spoznaji da je najprikladnija i najučinkovitija intervencija ona koja se oslanja na njihove specifične potrebe i potencijale. Iako ova spoznaja intuitivno stoji iza kontinuiranih reformi propisa i prakse u svijetu, novija istraživanja sada snažno i potvrđuju da intervencije temeljene na dobroj procjeni određenih rizika, potreba i kapaciteta maloljetnih počinitelja imaju najveću šansu. ${ }^{15}$

U državama koje imaju dobro razvijene strategije za unaprjeđenje maloljetničkog sudovanja razvijeni su tako vodiči, u obliku smjernica ili kao obvezujući materijal, a

9 Mears, Sentencing Guidelines and the Transformation of Juvenile Justice in the 21st Century, 6-19.

10 Dunkel, Juvenile Justice Systems in Europe, 32.

11 Dunkel, Juvenile Justice Systems in Europe, 33. Vidi i: John Pratt, Penal Populism (London, New York: Routledge - Taylor \&Francis Group, 2006.), 8-49.

12 Dunkel, Juvenile Justice Systems in Europe, 35.

13 Pratt, Penal Populism, 8-49.

14 Ženevska deklaracija o pravima djeteta, 1924., Deklaracija o pravima djeteta UN-a, 1959., UN Konvencija o pravima djeteta, 1989.; Standardna minimalna pravila UN-a za maloljetničko pravosuđe, 1985., Standardna pravila Pravila UN-a za zaštitu maloljetnika lišenih slobode, 1990., Standardna minimalna pravila UN-a za mjere alternative institucionalnom tretmanu, Europska pravila za maloljetne počinitelje kaznenih djela podvrgnutih sankcijama i mjerama, 2008.

15 Vidi u: Sandy Jung i Edward P. Rawana, „Risk and need Assessment of Juvenile Offenders“, Criminal Justice and Behaior 26, br. 1 (1999): 69-89; Mark W. Lipsey, „Can rehabilitative programs reduce the recidivism of juvenile offenders? An inquiry into the effectiveness of practical programs“, Virginia Journal of Social Policy and Law 6 (1999): 611-641; Francis T. Cullen i Paul Gendreau, „Assessing correctional rehabilitation: Policy, practice, and prospects“, u: Criminal justice: Policies, processes, and decisions of the criminal justice system, ur. J. Horney, str. 109-175. (Washington, DC: National Institute of Justice, 2000.). 
1955. u državi Teksas postavljen je i model. ${ }^{16}$ Oni olakšavaju procese maloljetničkoga sudovanja jer, s jedne strane, olakšavaju ujednačavanje sudske prakse, a s druge, balansiranje između različitih, katkad suprotnih ciljeva. To su, primjerice: pravedno, dosljedno i proporcionalno sankcioniranje, punitivni nasuprot rehabilitativnom principu te evaluiranje različitih posredujućih čimbenika pri kriminalnoj aktivnosti i pri budućoj rehabilitaciji. ${ }^{17}$

Od suda za maloljetnike se, dakle, očekuje da donese najbolju odluku u interesu djeteta. Pritom se podrazumijeva da raspolaže dostatnom količinom i profesionalnim tumačenjem relevantnih podataka koji se odnose na procjenu rizika za buduće delinkventno ponašanje te na tretmanske potrebe.

Nažalost, u više stotina dokumenata koje su prethodno pregledale autorice ovog rada radi postavljanja kvalitetnog okvira istraživanja te $u$ analizama kasnije spomenutih hrvatskih autora, rizici i potrebe kao kriterij za odabir maloljetničke sankcije te njihovo dovođenje u vezu s odabirom sankcije, gotovo se uopće ne spominju.

Sudeći prema radovima hrvatskih autora, ${ }^{18}$ a neki su od njih temeljeni na znanstvenim istraživanjima ili analizama slučajeva, ${ }^{19}$ kvaliteta sudovima dostupnih podataka pati od brojnih nedostataka. Taj je problem otvoren već više desetljeća.

Još su Singer i suradnici ${ }^{20}$ proveli istraživanje na velikom uzorku od 1190 ispitanika na području bivše države (uključujući i hrvatski subuzorak) i na temelju multivarijatnih obrada podataka, zaključili da je prijedlog centra za socijalnu skrb (tada organa starateljstva) samo nedosljedna replikacija prijedloga državnog odvjetnika (tada javnog tužioca). Pritom je stupanj samovolje centra u donošenju odluke o prijedlogu sankcije, znatno veći. Osobito je zabrinjavajuće bilo da je prijedlog centra pod manjim

16 Mears, Aesthetic Labor for the Sociologies of Work, Gender, and Beauty, 1330-1343.

17 James C. Howell, Guide for implementing the comprehensive strategy for serious, violent, and chronic juvenile offenders (Washington, DC: Office of Juvenile Justice and Delinquency Prevention, 1995.), 219-245.

18 Vidi više: Marija Koren Mrazović, „Maloljetnici i mlađi punoljetnici s poremećajima u ponašanju u tretmanu socijalne skrbi u Republici Hrvatskoj“, Kriminologija i socijalna integracija 6, br. 2 (1998): 141-152; Franjo Hirjan i Mladen Singer, Komentar Zakona o sudovima za mladež $i$ kaznenih djela na štetu djece i maloljetnika (Zagreb: Nakladni zavod Globus, 2002.); Ante Carić i Ivan Kustura, „Kamo ide hrvatsko maloljetničko kazneno zakonodavstvo?“, Zbornik radova Pravnog fakulteta u Splitu 47, br. 3 (2010): 605-620; Nivex Koller-Trbović, Anja Mirosavljević i Ivana Jeđud Borić, Procjena potreba djece i mladih s problemima u ponašanju-konceptualne i metodičke odrednice (Zagreb: Ured UNICEF-a za Hrvatsku, 2017.).

19 Vidi: Singer, Momirović i Kovačević, Kriteriji sudova pri izricanju sankcija maloljetnicima, 48-121; Ljiljana Mikšaj-Todorović i Mladen Singer, „Obavijest o prethodnim intervencijama društvenih institucija prema malodobnim počiniteljima kaznenih djela i/ili njihovim obiteljima kao kriterij izricanja odgojnih mjera“, Zbornik Pravnog fakulteta Sveučilišta u Rijeci 19, br. 1 (1998): 11-25; Đurđa Križ, „Kriteriji za odabir odgojnih mjera maloljetnicima u svjetlu primjene Zakona o sudovima za mladež“, Hrvatski ljetopis za kazneno pravo i praksu 6, br. 2 (1999): 366-368; Rittossa, Božićević Grbić, Zakon o sudovima za mladež - reformski zahvati i praktične dileme, 615-667; Marina Zagorec, „Problematika postupanja prema maloljetnim počiniteljima kaznenih djela“, Policija i sigurnost 26, br. 4 (2017): 283-301; Ivana Radić, „Hrvatski sustav maloljetničkih sankcija: trenutačno stanje i prijedlozi za promjenu“, Hrvatski ljetopis za kaznene znanosti i praksu 24, br. 1(2017): 3-115.

20 Singer, Momirović, Kovačević, Kriteriji sudova pri izricanju sankcija maloljetnicima, 48-121. 
utjecajem podataka o ličnosti maloljetnika, a pod većim utjecajem vrste i modaliteta izvršenja kaznenog djela od prijedloga državnog odvjetnika. Isto tako, centar za socijalnu skrb ne pridonosi ukupnoj slici niti svojim specifičnim informacijama o socijalnim prilikama maloljetnika. Naime, prema autorima, činjenica da centar skuplja te podatke, još ne znači da su oni pretvoreni u učinkovite informacije, ako se njima mogu smatrati one koje su bitne za donošenje konačne odluke u kaznenom postupku. Tako autori zaključuju da su centri za socijalnu skrb samo generator podataka, ali ne i sustav koji te podatke organizira u jedan koherentan sklop.

Državno je odvjetništvo u Zagrebu 1982. provelo studiju o izvješćima koja su centri za socijalnu skrb slali sudovima ${ }^{21}$ te je zaključeno da su ona prekratka, da izostaju neke bitne informacije o ranijem životu korisnika, odnosima u obitelji, problemima školovanja, načinu korištenja slobodnog vremena te da se pišu sporo i da sporo dolaze na sud.

Ministarstvo nadležno za područje socijalne skrbi tijekom 1984. analiziralo je nalaze i mišljenja napisana za potrebe suda ${ }^{22}$ koje su uputili tadašnji centri za odgoj djece i mladeži i centri za socijalnu skrb. Dobiveni su rezultati ukazali na šturost nalaza, podatci su uzimani samo iz jednog izvora, pojedini nalazi bili su opterećeni prevelikom informativnošću te brojnim nebitnim pojedinostima, a izostao je jasan opis okolnosti pod kojima su problemi manifestirani i podatci o tome koji su određeni oblici problema u ponašanju ili kaznenog djela. Nadalje, nisu bili navedeni motivi manifestnog ponašanja, nalazi su bili nepregledno usustavljeni ili pak previše shematizirani, preporuke su bile udaljene od prakse, a prijedlozi nisu bili dostatno argumentirani.

Križ ${ }^{23}$ je analizom slučajeva, utvrdila da u Hrvatskoj nema ujednačenih kriterija za izricanje odgojnih mjera usprkos naoko jasnih kriterija o njihovom predlaganju i izricanju navedenih Zakonom o sudovima za mladež iz 1997. Suvremenije analize, nažalost, potvrđuju ove zaključke. Nekoliko desetljeća nakon opisanih istraživanja i analiza, suvremeni autori gotovo isto vide problem. Tako, Rittossa i Božićević Grbić ${ }^{24}$ na temelju provedene analize, (također) uočavaju nedostatke i pogreške posebice pri obrazlaganju odabira vrste maloljetničkih sankcija od strane sudaca, što ističu kao posebno problematično jer se time ne mogu polučiti specijalno preventivne svrhe. Navedene autorice zaključuju da je temeljni nedostatak donesenih rješenja o odgojnoj mjeri, šturost u prikupljanju podataka o maloljetniku i njihovom dovođenju u vezu s odabranom maloljetničkom sankcijom, dok se u obrazloženju ne objašnjava koje okolnosti opravdavaju izricanje konkretne odgojne mjere.

Radić $^{25}$ zaključuje da usprkos relativno dobrim zakonskim rješenjima, moderni sustav maloljetničkih sankcija u hrvatskoj praksi ne djeluje u skladu sa svojom svrhom.

21 Koller-Trbović, Mirosavljević, Jeđud Borić, Procjena potreba djece i mladih s problemima $u$ ponašanju, 114.

22 Koller-Trbović, Mirosavljević, Jeđud Borić, Procjena potreba djece i mladih s problemima u ponašanju, 114.

23 Križ, Kriteriji za odabir odgojnih mjera maloljetnicima u svjetlu primjene Zakona o sudovima za mladež, 366-368.

24 Rittossa, Božićević Grbić, Zakon o sudovima za mladež, 615-667.

25 Radić, Hrvatski sustav maloljetničkih sankcija, 3-115. 
Glavne razloge vidi u neučinkovitoj sudskoj politici izricanja maloljetničkih sankcija, koja rezultira time da se određene sankcije izriču neodgovarajućim maloljetnim počiniteljima.

Gotovo je nevjerojatno da se, ne samo brojni istraživači, već i praktičari2 ${ }^{26}$ slažu oko ozbiljnog problema u prikupljanju i sažimanju potrebnih podataka. S druge strane, iznimno je razgranata mreža različitih dionika koji u tom postupku sudjeluju i to $\mathrm{u}$ velikom preklapanju zadataka. Pritom su neki dionici (policija, zdravstvene ustanove, neke socijalne i druge ustanove) pretežno generatori podataka, a glavni su generator uz istodobno sastavljanje izvješća ili nalaza i mišljenja te prijedloga odgojne mjere, centri za socijalnu skrb.

U konačnici, stručni suradnik pri državnom odvjetništvu, dužan je sastaviti sažeto izvješće za državnog odvjetnika koji predlaže odgojnu mjeru, a po potrebi prikupiti i dodatne informacije. Stručni suradnik to čini na temelju prikupljene dokumentacije i procjene maloljetnikovih osobina i uvjeta odrastanja nakon razgovora s njim i njegovim roditeljima/skrbnicima. Stručni suradnik pri sudu prikuplja i sve relevantne informacije, ali za potrebe suda.

Kako je centar za socijalnu skrb najvažniji generator podataka od kojega se inicijalno očekuje da te podatke sintetizira i daje obrazloženi prijedlog odgojne mjere (iako ovo potonje izrijekom ne piše u zakonskom i podzakonskim aktima), postavlja se pitanje uzajamne neovisnosti ovih dionika. Naime podatci, njihova sinteza i prijedlog odgojne mjere centra za socijalnu skrb ujedno čine i istovjetni temeljni materijal kojim se služe državni odvjetnici i suci za maloljetnike (sa svojim stručnim suradnicima).

Važno je naglasiti da su pri centrima za pružanje usluga zajednici ili domovima za odgoj djece i mladeži odjeli timske procjene čija je svrha kreiranje specijaliziranih nalaza i mišljenja u svim fazama kaznenog postupka, a koji također imaju pravo predlaganja odgojne mjere. Nalaz i mišljenje odjela timske procjene dostavlja se naručitelju što znači bilo kojoj od prethodno opisanih instanci.

Odjel timske procjene specijaliziran je upravo za postupke procjene djece i mladih s poremećajima u ponašanju, s timovima koji se posebno educiraju (uključujući i primjenu dijagnostičkih instrumenata) te jedini ima mogućnost stacionarne procjene što uključuje opservaciju u cjelodnevnim strukturiranim uvjetima, u heterogenim grupama, kroz različite životne situacije tijekom dana. Uz to odjel može utvrditi somatsku ili psihičku bolest u suradnji sa zdravstvenim ustanovama (primjerice, uz suglasnost roditelja/skrbnika, to može biti testiranje na psihoaktivne tvari, ginekološki pregled, pregled psihijatra i dr.).

Nelogično je, stoga, da se tako specijalizirane usluge odjela timske procjene vezano za počinitelje kaznenih djela u praksi koriste vrlo rijetko, a protekom su

26 Koren Mrazović, Maloljetnici i mlađi punoljetnici s poremećajima u ponašanju u tretmanu socijalne skrbi u Republici Hrvatskoj, 141-152; Gordana Lulić Čavar, „Neki aspekti evaluacije učinkovitosti tijeka izvršenja odgojne mjere upućivanja u disciplinski centar za maloljetnike“, Kriminologija i socijalna integracija 3, br. 1 (1995): 53-70; Križ, Kriteriji za odabir odgojnih mjera maloljetnicima u svjetlu primjene Zakona o sudovima za mladež, 366-368; Melita Božićević Grbić, Mirta Kuharić, Zakon o sudovima za mladež - primjena u praksi, Priručnik za polaznike/ice, Izrada obrazovnih materijala, Zagreb: 2017. 
vremena sve rjeđe. ${ }^{27}$ Protok informacija vrlo je raznolik među svim navedenim dionicima (grafikon 1).

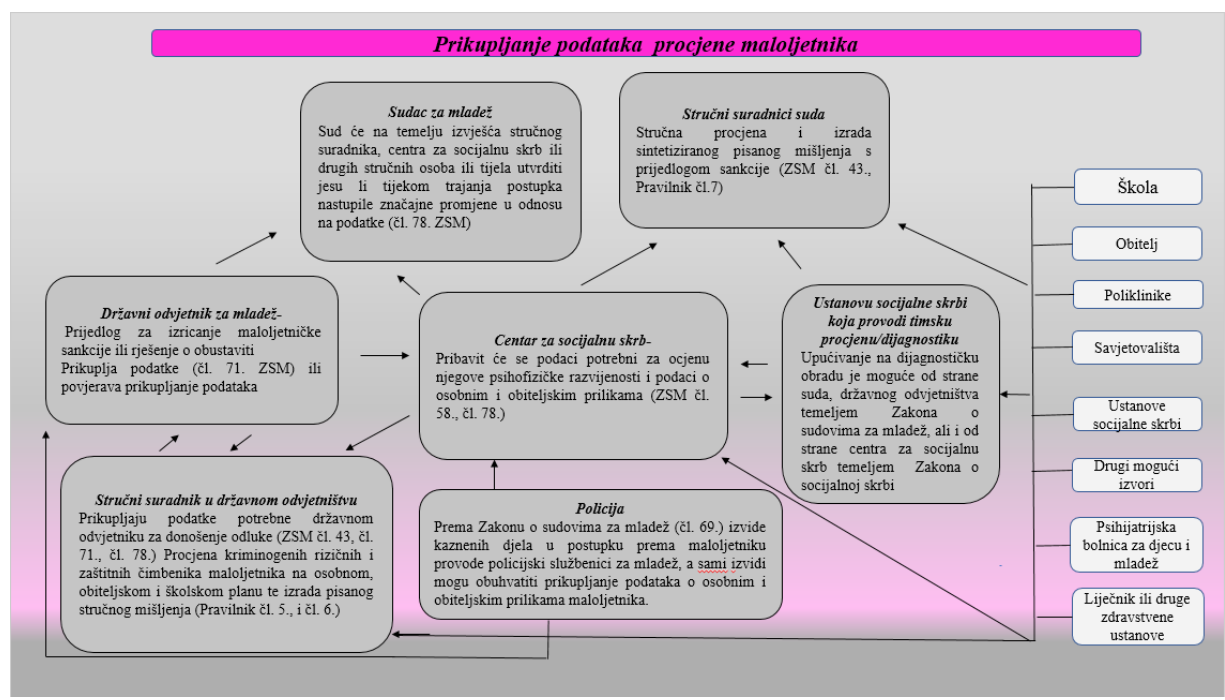

Grafikon 1. Prikaz dionika u prikupljanju podataka i protoka podataka

Shematski prikaz uzajamnih relacija generatora podataka (sa ili bez prijedloga odgojne mjere u svom izvješću) pokazuje kompleksnost potoka informacija. Pritom, shema vjerojatno nije do kraja precizirana, jer je propisi jasno ne definiraju, niti zabranjuju sudjelovanje i drugih dionika, kao niti načine (primjerice, neformalne) prikupljanja podataka. Složenost protoka informacija sama po sebi nije loša. Jasno je da su sucu za mladež, samim time što je na njemu teret odluke o odgojnoj mjeri, potrebni najpotpuniji i sustavno strukturirani podatci, a to znači činjenice, procjene i preporuke drugih stručnih dionika. ${ }^{28}$ Međutim, otvara se nekoliko ozbiljnih pitanja:

1. Ako je isti materijal (primarno izvješće centra za socijalnu skrb) temelj donošenja procjene najbolje odgojne mjere, znači li to da isti podatci za različite dionike imaju različito značenje? Ima li osnove očekivati da će tri predlagatelja odgojne mjere (državni odvjetnik, stručni suradnik suda i centar za socijalnu skrb), na temelju istih podataka donijeti različite preporuke ,u najboljem interesu djeteta"? Ako je tako, onda su stručne osnove procjene svedene na puko arbitriranje umjesto da se temelje na procedurama i standardima. Isto tako, ako je vidljivo preklapanje u predloženim i izrečenim odgojnim mjerama između svih triju dionika, onda je u pitanju nepotrebno „dupliranje" poslova. Intenzitet je ovoga preklapanja dio istraživanja u ovom radu.

2. Postoji li standard, vodič ili naputci oko prikupljanja podataka (koje sve i posebno važno, kako prikupiti), te koje smatrati relevantnima i kako ih dovesti u vezu s prijedlogom odgojne mjere ili svaki dionik to čini prema nekom vlastitom (pisanom

27 Koller-Trbović, Mirosavljević, Jeđud Borić, Procjena potreba djece i mladih s problemima u ponašanju, 114.

28 Uz to, predstavnik centra za socijalnu skrb pozvat će se prema Zakonu o sudovima za mladež (čl. 84.) na sjednicu vijeća ili raspravu (čl. 86.), pri čemu je iznimno važno njegovo mišljenje. 
ili nepisanom) standardu?

3. Ako nema standarda, je li time osigurano pravo svakoga maloljetnog počinitelja biti tretiran s jednakom pozornošću, da se za njega prikupe svi podatci, da se na temelju istih stručnih postupaka odaberu oni relevantni te da se na kraju predloži najbolja odgojna mjera?

U svjetlu zaključaka ranije u radu spomenutih autora, čini se da odgovori na ova pitanja idu na štetu po organizaciju i funkcioniranje sustava maloljetničkog sudovanja.

Pritom se posebno ističe otvoreno pitanje uloge prethodno spomenutih odjela timske procjene čiji je cilj kvalitetna procjena svih okolnosti i na tome temeljene preporuke odgojne mjere. Takvih je odjela sedam, koji u Republici Hrvatskoj imaju mogućnost stacionarne timske procjene (u Karlovcu, Osijeku, Puli, Rijeci, Splitu, Zadru i Zagrebu) i logično je za očekivati da će barem njihovi postupci biti standardizirani. No, kako nema obvezujućih dokumenata, čini se da u praksi čak i oni djeluju prema vlastitom odabiru metoda i tehnika procjene. Ovdje, međutim leži potencijal za razvijanje i primjenu dobre prakse.

\section{CILJEVI RADA}

U ovom su radu postavljena tri cilja:

1. utvrditi potpunost dokumentacije centara za socijalnu skrb koja se, nakon izricanja odgojne mjere, dostavlja ustanovama za provođenje odgojnih mjera,

2. utvrditi postoje li razlike u kvaliteti (izraženoj u kvantiteti podataka) dokumentacije među centrima za socijalnu skrb pri predlaganju odgojnih mjera i

3. usporediti prijedloge odgojnih mjera stranaka u postupku s odlukom nadležnog suda.

\section{METODOLOGIJA}

\subsection{Uzorak}

Glavni je uzorak $(\mathrm{N} 1=68)$ dokumentacija (centara za socijalnu skrb i rješenja sudova) o korisnicima koji su, zbog počinjenja kaznenog djela, na izvršenje odgojne mjere upućivanja u disciplinski centar upućeni tijekom tri godine (od 2016. do 2018.). Kako u devet slučajeva dokumentacija centara za socijalnu skrb (daljnjem tekstu: izvješća) iz određenih razloga ${ }^{29}$ nije bila priložena u spisima, u pojedinim obradama analiziran je uzorak $\mathrm{N} 2=59$.

Iako je istraživanje usmjereno na organizaciju izvješća, količinu i vrstu sadržanih informacija te na jednu odgojnu mjeru, nema razloga vjerovati da se izvješća, općenito po svojoj strukturi, razlikuju bez obzira na to koja je odgojna mjera predložena i koji je ishod sudske odluke.

29 Dokumentacija je u drugim spisima radi ranijih postupaka koji nisu bili kazneni ili je nepotrebna jer se s mjerom nije ni započelo. 


\subsection{Mjerni instrument}

S obzirom na ciljeve rada, u korištenom instrumentu pozornost nije usmjerena na obilježja maloljetnih počinitelja, već na vrstu i kvantitetu prikupljenih podataka.

Za istraživanje je kreiran upitnik pod nazivom Analiza dokumentacije korištene u postupku predlaganja odgojnih mjera maloljetnicima - APOM. U ovom se radu koristi samo dio upitnika (cjeline A i C), koji se odnosi na analizu izvješća centara za socijalnu skrb i prijedloge stranaka u postupku. Upitnik se popunjavao uvidom u pristiglu dokumentaciju.

Upitnik se sastojao od tri logičke cjeline koji ukupno čine 171 varijablu. Logičke cjeline su: (A) Lista sadržaja dokumentacije centra za socijalnu skrb - 149 varijabli, (B) Kazneno djelo, sankcija i Recidivizam - 15 varijabli i (C) Prijedlozi „stranaka“ u postupku - 7 varijabli.

Cjelina (A) primijenjenog upitnika obuhvatila je pitanja koja utvrđuju postojanje određenog podatka ili ne u dostavljenom izvješću centra za socijalnu skrb. Sve varijable tog dijela upitnika (ukupno 149) sastavljene su uzimajući u obzir čl. 8. i čl. 78. Zakona o sudovima za mladež te čl. 127. Zakona o socijalnoj skrbi i čl. 5., st. 8. i st. 9. te čl. 6. st. 1. i st. 2. Pravilnika o radu stručnih suradnika izvanpravne struke na poslovima delinkvencije mladih i kaznenopravne zaštite djece u državnim odvjetništvima i na sudovima te profesionalne standarde ${ }^{30}$ koji nisu propisani niti jednim obvezujućim aktom bilo koje razine, ali su opisani i argumentirani u brojnim, posebno znanstvenim radovima, iz kojih proizlaze najvažnija obilježja rizika i tretmanskih potreba.

\subsection{Metode obrade podataka}

U radu je korišten program Microsoft Office Excel za obradu i analizu primarnih podataka. Prikupljeni su podatci analizirani primjenom metoda deskriptivne statističke analize (apsolutne i relativne frekvencije, aritmetičke sredine) i prikazani su tablično i grafikonima.

\section{REZULTATI I RASPRAVA}

\subsection{Potpunost izvješća centara za socijalnu skrb}

Kako je navedeno, prvi se cilj rada odnosi na utvrđivanje potpunosti priložene dokumentacije (dalje: izvješća) centara za socijalnu skrb, nakon izricanja odgojne mjere dostavljene ustanovama za provođenje odgojnih mjera. Analiza je provedena na cjelini A Upitnika APOM. Izvješća su ustanovama za izvršavanje odgojnih mjera potrebna kako bi se ravnale pri kreiranju individualiziranog tretmana.

Prvo što je, analizom cjelokupne dokumentacije, uočeno da ona nije strukturirana, već da svako izvješće ima svoj odabir prikazanih podataka te vlastiti slijed i logiku

30 Stručni standardi na polju procjene detaljno su opisani u Priručniku Procjena potreba djece $i$ mladih s problemima u ponašanju - konceptualne $i$ metodičke odrednice, autorica KollerTrbović, Mirosavljević i Jeđud Borić. 
njihovog prikaza.

Kako je vidljivo iz grafikona 2., raspršenost rezultata na svim je upitnicima nevjerojatno velika, što ukazuje na velike razlike u dokumentaciji centara za socijalnu skrb, od najmanje sedam podataka u najslabije ispunjenom izvješću do najviše $115 \mathrm{u}$ najbolje ispunjenom izvješću.

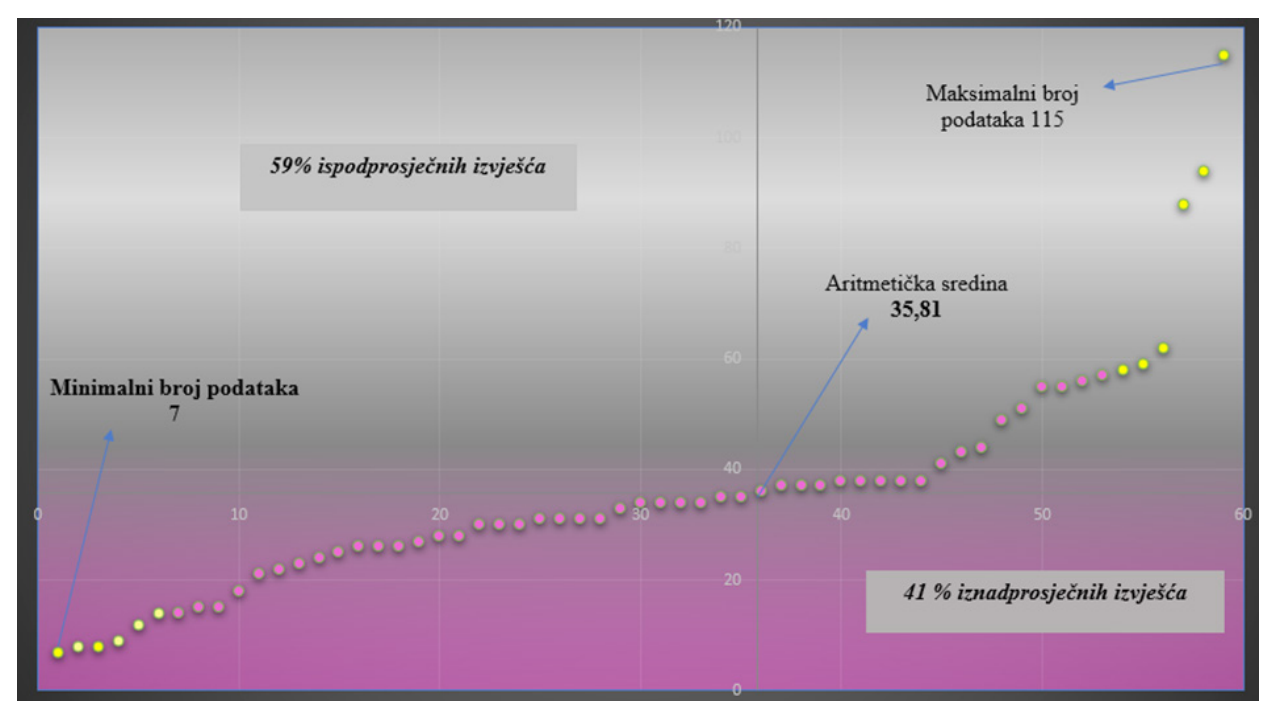

Grafikon 2. Distribucije rezultata na upitniku (N2)

Distribucija se rezultata ne može prikazati krivuljom jer je standardna devijacija (mjera raspršenosti podataka u skupu) čak 20.

Iz tablice 1. vidljivo je da je prosječni broj podataka na ukupnom uzorku četverostruko manji od najvećeg mogućeg (149 ili $100 \%$ ), i to tek 35,81 podatak ili $24 \%$ svih traženih podataka.

Tablica 1. Prosječni broj unesenih podataka (N2)

\begin{tabular}{|c|c|c|c|}
\hline $\begin{array}{c}\text { Najveći mogući broj } \\
\text { podataka }\end{array}$ & $\begin{array}{c}\text { Najmanji broj stvarno } \\
\text { unesenih podataka }\end{array}$ & $\begin{array}{c}\text { Najveći broj stvarno } \\
\text { unesenih podataka }\end{array}$ & Aritmetička sredina \\
\hline 149 & 7 & 115 & 35,81 \\
$100 \%$ & $5 \%$ & $77,2 \%$ & $24,0 \%$ \\
\hline
\end{tabular}

U 23 slučaja (39 \% N2 uzorka) broj unesenih podataka veći je od prosjeka, ali u rasponu od 37 do 115 podataka. Zbog velikog raspona, izračunati su najveći i najmanji prosjeci broja podataka. Najveći prosjek broja unesenih podataka izračunat je analizom $10 \%$ najbolje ispunjenih upitnika, što je izračunato na subuzorku od šest izvješća (tablica 3.). 
Tablica 2. Najveći prosjek iskazan na temelju $10 \%$ najbolje ispunjenih upitnika (N2)

\begin{tabular}{|c|c|c|c|}
\hline $\begin{array}{c}\text { Najveći mogući broj } \\
\text { podataka }\end{array}$ & $\begin{array}{c}\text { Najmanji broj stvarno } \\
\text { unesenih podataka }\end{array}$ & $\begin{array}{c}\text { Najveći broj stvarno } \\
\text { unesenih podataka }\end{array}$ & Aritmetička sredina \\
\hline 149 & 58 & 115 & 79,3 \\
$100 \%$ & $39 \%$ & $77,2 \%$ & $53,2 \%$ \\
\hline
\end{tabular}

Promatrajući samo subuzorak najuspješnijih izvješća prema navedenom kriteriju, vidljivo je da ona prosječno pružaju tek $53 \%$ traženih podataka.

Istim je načelom izračunat i najmanji prosjek broja unesenih podataka temeljen na 10 \% najmanje uspješnih unosa, što je također uključilo šest slučajeva.

Tablica 3. Najmanji prosjek iskazan na temelju $10 \%$ najlošije ispunjenih upitnika (N2)

\begin{tabular}{|c|c|c|c|}
\hline $\begin{array}{c}\text { Najveći mogući broj } \\
\text { podataka }\end{array}$ & $\begin{array}{c}\text { Najmanji broj stvarno } \\
\text { unesenih podataka }\end{array}$ & $\begin{array}{c}\text { Najveći broj stvarno } \\
\text { unesenih podataka }\end{array}$ & Aritmetička sredina \\
\hline 149 & 7 & 14 & 9,7 \\
$100 \%$ & $4,7 \%$ & $9,4 \%$ & $6,51 \%$ \\
\hline
\end{tabular}

Podatci iz tablice 3. izgledaju nestvarno. Od najvećeg mogućeg broja podataka (149) u analiziranih šest izvješća nalazi se tek između sedam i 14 podataka po pojedinom slučaju.

Postavlja se pitanje na temelju čega je sud djelovao u najboljem interesu djeteta? Jesu li preostali podatci uopće prikupljeni pa nisu dostavljeni ili nisu ni prikupljeni? Stoga se pojavljuje problem dodatnog/ponovnog prikupljanja podataka za potrebe samog tretmana. Hoće li ustanova koja provodi tretman sada poduzeti/ponoviti sve radnje da bi dobila podatke koji su joj mogli/trebali biti dostavljeni jer su ionako prikupljani u svrhu donošenja najbolje odluke suda?

\subsection{Razlike u popunjenosti izvješća s obzirom na pojedine centre za socijalnu skrb}

Drugi je cilj rada bio utvrditi razlike u popunjenosti dokumentacije među centrima za socijalnu skrb. Kako su već cjelokupni podatci o potpunosti analizirane dokumentacije centara za socijalnu skrb pokazali veliku raspršenost rezultata na upitniku, jasno je da su razlike prema kriteriju centara za socijalnu skrb također iznimno velike.

Glavni je problem u tumačenju rezultata činjenica da je za većinu od analiziranih 20 centara za socijalnu skrb u analiziranom razdoblju dostavljen mali broj izvješća i to: od jednog izvješća (osam centara) do 9 izvješća (centri Čakovec i Pešćenica). Ipak, i dostavljeni materijal omogućuje nižu razinu zaključivanja. Centri su uspoređeni prema prosječnom broju unesenih podataka bez obzira na to koliko je izvješća dostavljeno iz pojedinog centra. U grafikonu 3. prikazani su centri za socijalnu skrb s brojem predmeta, prema kriteriju najbolje ispunjenih izvješća. 


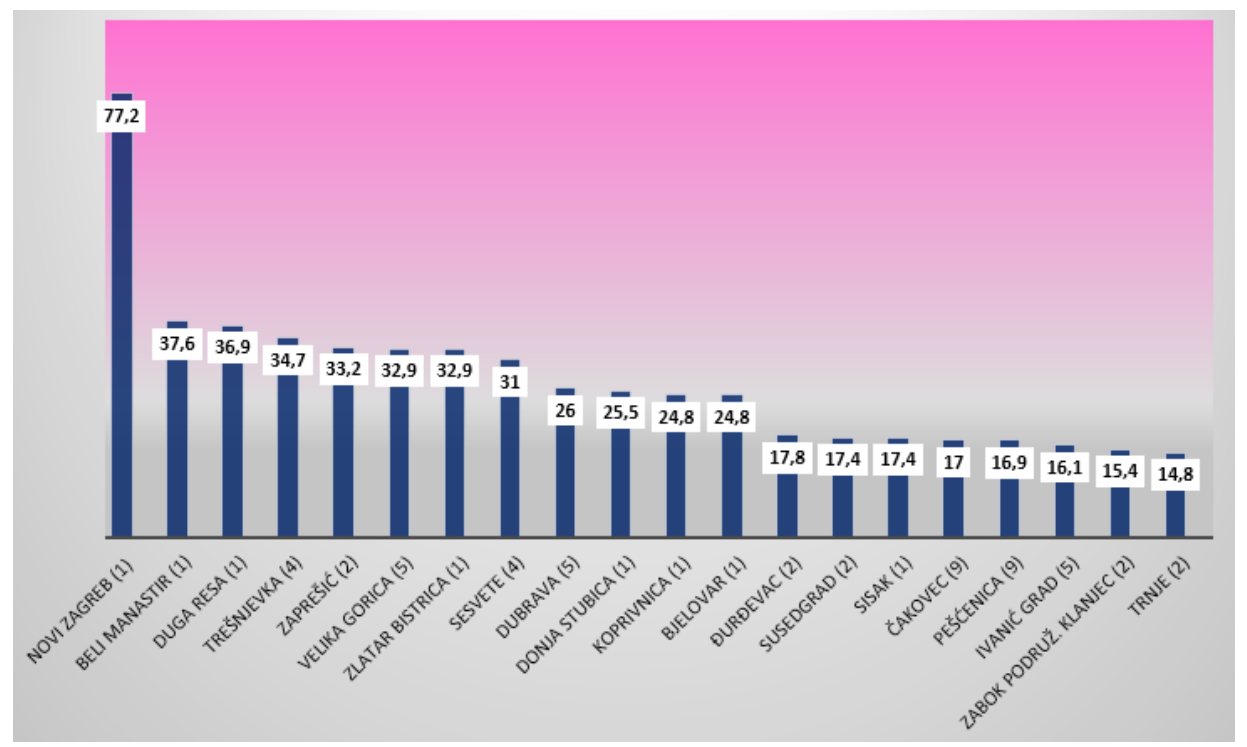

Grafikon 3. Centri za socijalnu skrb, broj izvješća, potpunost izvješća

Najviše je podataka zabilježeno u izvješću Centra za socijalnu skrb Novi Zagreb (77 \% traženih podataka). No, njegova je posebnost u tome što je riječ o jedinom izvješću koje je dostavljeno iz tog centra te $u$ činjenici da je taj centar u potpunosti koristio i priložio dokumentaciju timske procjene Centra za pružanje usluga zajednici Zagreb - Dugave.

Zanimljivo je da još šest centara za socijalnu skrb u svojim izvješćima navodi da su na raspolaganju imali dokumentaciju timske procjene Centra za pružanje usluga zajednici Zagreb - Dugave, ali je nisu u potpunosti iskoristili u sastavljanju izvješća, čime su se, u pravilu, svrstali u kategorije prosječno slabije ispunjene dokumentacije. Iznimno je slaba prosječna potpunost (ispod $20 \%$ ) dokumentacije čak osam centara za socijalnu skrb, pri čemu najlošije pojedinačno izvješće centra za socijalnu skrb Ivanić Grad daje samo sedam podataka. Osim razlike u popunjenosti dokumentacije, usporedbom centara za socijalnu skrb, uočena je još jedna posebnost. Naime, i kod pojedinog centra popunjenost podataka se izrazito razlikuje. Iako su svi podatci podobni za analizu, navest će se samo neki primjeri. Tako je prosječna popunjenost dokumentacije (dostavljena četiri izvješća) Centra za socijalnu skrb Trešnjevka $34,7 \%$, ali jedno je izvješće tog centra popunjeno na razini $59 \%$, a čak su dva njegova izvješća ušla u $10 \%$ najbolje ispunjenih izvješća, analiziranih u ranijem poglavlju.

S druge strane, među pet izvješća Centra za socijalnu skrb Velika Gorica najbolje pojedinačno izvješće ima popunjenost na razini 63,1 \% traženih podatka, a najlošije na razini $16,8 \%$.

Pregled dokumentacije i prije pristupa istraživanju, a potom i analiza popunjenosti cjelokupne dokumentacije ukazali su na nedostatak minimuma strukture u sastavljanju izvješća. To najbolje prikazuje i podataka da u četiri slučaja nije navedena niti godina rođenja maloljetnika. 
U praksi nema formalnih ni neformalnih naputaka prema kojima bi neke podatke trebalo obavezno prikupiti, a ostale možda samo ako su relevantni. Stoga ne čudi da se izvješća razlikuju, te da su pojedini centri za socijalnu skrb temeljitiji u njihovu sastavljanju od drugih. Ipak, začudno je da, čini se, nema niti nekog internog dogovora kod pojedinih centara koji bi ujednačio oblik sastavljanja izvješća (što bi onda nužno uključivalo i ujednačavanje postupaka prikupljanja podataka).

\subsection{Slaganje prijedloga odgojne mjere s odlukom suda}

Treći je cilj rada bio usporediti prijedloge odgojnih mjera stranaka u postupku s odlukom nadležnog suda. Uvodno je već napomenuto da su izvješća centara za socijalnu skrb (tako neujednačena kako pokazuju prethodni podatci) osnovni bazen podataka za državnog odvjetnika i sud, koji uvijek mogu tražiti i dopune, najčešće putem svojih stručnih suradnika.

Ta su izvješća polazišna točka za pisanje novih izvješća od strane stručnih suradnika, koji mogu primjerice, ponoviti razgovor s članovima obitelji maloljetnika iako je to obavio nadležni centar za socijalnu skrb ili to učiniti ako centar nije obavio takav razgovor.

Prethodni podatci ukazuju na potrebu da, primjerice, ako izvješće centra za socijalnu skrb ima samo sedam podataka cjelokupan posao obave stručni suradnici. Obrnuto, kad je izvješće centra za socijalnu skrb vrlo detaljno, stručni suradnik treba dodatno zatražiti tek nekolicinu dodatnih podataka ako su mu potrebni i svoje izvješće napisati prema predlošku izvješća centra za socijalnu skrb. No, i dalje sve ostaje na slobodnoj procjeni količine i vrste podataka koji su potrebni, kako bi sud donio najbolju odluku.

U svjetlu činjenice da su generirani podatci različiti i neujednačeni u njihovom prikupljanju, te da na temelju tako prikupljenih podataka različiti dionici predlažu i odgojnu mjeru, često bez dovođenja u vezu prikupljenih podataka s obrazloženjem upravo određenog prijedloga, ${ }^{31}$ moglo bi se očekivati da stranke u postupku (uključujući predstavnike centra za socijalnu skrb), najčešće imaju različite prijedloge o odgojnoj mjeri koju bi bilo uputno izreći. S druge strane, ako se i sud i odvjetništvo uglavnom oslanjaju na (tako neujednačena) izvješća i prijedloge centara za socijalnu skrb, onda bi istovjetnost prijedloga trebala biti visoko prisutna.

$\mathrm{S}$ obzirom na neujednačena i podatcima često vrlo manjkava izvješća centara za socijalnu skrb, analizom preklapanja prijedloga i odluke suda uzeto je u obzir i kazneno djelo te recidivizam, kako bi se mogla utvrditi određena pravilnost, ako postoji.

U tablici 4. dan je prikaz samo onih 12 slučajeva (17,6 \%) svih promatranih slučajeva u kojima je došlo do jednostrukog ili višestrukog nepreklapanja prijedloga odgojne mjere predlagača međusobno i/ili s odlukom suda.

31 U ovom su istraživanju centri za socijalnu skrb odgojnu mjeru predložili tek u 23,7 \% slučajeva, a argumentirali prijedlog u $18,6 \%$ slučajeva. 
Tablica 4. Preklapanje različitih prijedloga odgojne mjere i odluke suda (N1)

Predlagatelj i prijedlog

\begin{tabular}{|c|c|c|c|c|c|}
\hline $\begin{array}{l}\text { Kaznena djela i recidivizam } \\
\text { (R) s brojem prethodno } \\
\text { počinjenih djela (x) }\end{array}$ & $\begin{array}{l}\text { DO težu } \\
\text { mjeru od } \\
\text { CZSS-a }\end{array}$ & $\begin{array}{l}\text { DO težu } \\
\text { mjeru od } \\
\text { SSS-a }\end{array}$ & $\begin{array}{l}\text { DO } \\
\text { težu od } \\
\text { odluke } \\
\text { suda }\end{array}$ & $\begin{array}{l}\text { SSS težu } \\
\text { mjeru od } \\
\text { CZSS-a }\end{array}$ & $\begin{array}{l}\text { CZSS težu } \\
\text { mjeru od } \\
\text { odluke } \\
\text { suda }\end{array}$ \\
\hline $\begin{array}{l}\text { Neizvršavanje posebnih } \\
\text { obveza ili odgojne mjere, } \\
\text { R (3) }\end{array}$ & & $*$ & & & \\
\hline Krađa, R (3) & & & $*$ & & \\
\hline Tjelesna ozljeda, prvo djelo & & & * & & * \\
\hline $\begin{array}{l}\text { Nepružanje pomoći, prvo } \\
\text { djelo }\end{array}$ & $*$ & & & $*$ & \\
\hline $\begin{array}{l}\text { Neizvršavanje posebnih } \\
\text { obveza ili odgojne mjere, } \\
\text { R (3) }\end{array}$ & & & $*$ & & $*$ \\
\hline $\begin{array}{l}\text { Oštećenje tuđe stvari, prvo } \\
\text { djelo }\end{array}$ & $*$ & $*$ & * & & \\
\hline Razbojništvo, R (1) & & $*$ & & & \\
\hline Teška krađa, R (2) & $*$ & & & & \\
\hline Krađa, R (1) & $*$ & $*$ & $*$ & & \\
\hline Teška krađa, R (1) & & & $*$ & & \\
\hline Krađa, R (3) & $*$ & $*$ & * & & \\
\hline Krađa, R (3) & $*$ & $*$ & * & & \\
\hline
\end{tabular}

DO = državni odvjetnik, CZSS = centar za socijalnu skrb, SSS = stručni suradnik pri sudu

U navedenih 12 slučajeva bilo kakvog zabilježenog nepreklapanja, vidljivo je da je državni odvjetnik taj koji predlaže težu mjeru u odnosu na ostale predlagatelje pa i u odnosu na konačnu odluku suda.

To je, na prvi pogled, razumljivo samom prirodom posla državnog odvjetnika. No, s druge strane, ako je „najbolji interes djeteta“ temeljno načelo djelovanja svih dionika, koje je to ključne elemente državni odvjetnik prepoznao (a ostali ili većina ostalih dionika nisu), a prema kojima bi teža mjera bila u boljem interesu djeteta?

Samo u tri slučaja, počinitelji kaznenog djela nisu ranije činili kaznena djela, a djela koja su sada predmetom odluke suda su: tjelesna ozljeda, ne pružanje pomoći i oštećenje tuđe stvari. I tu je državni odvjetnik predložio težu mjeru bilo u odnosu na odluku suda ili u odnosu na prijedlog centra za socijalnu skrb, a u zadnjem slučaju, u odnosu na prijedlog centra, stručnog suradnika pri sudu i samog suda. Teško da je u tim slučajevima na njegov prijedlog utjecala težina kaznenog djela ili činjenica da nije riječ o recidivistima. Jesu li u tim slučajevima njegova saznanja o malodobnom počinitelju i okolnostima izvršenja djela bila drukčija od onih kojima su raspolagali ostali dionici? 
Preklapanja ili nepreklapanja prijedloga dionika između sebe te s odlukom suda, mogu biti tema druge rasprave. U kontekstu je ovoga rada glavno pitanje koliko su se svi dionici oslonili na neujednačena i često vrlo manjkava izvješća centara za socijalnu skrb, a koliko su sami dopunjavali i filtrirali informacije koje su im na kraju bile osnova za predlaganje odgojnih mjera.

\subsection{Prijedlog održivoga modela standardiziranog prikupljanja podataka $i$ sastavljanja integriranih izvješća}

Kako je uvodno rečeno, svrha je rada, nakon istraživačkim postupkom utvrđene (ne)adekvatnosti u procesu prikupljanja podataka kao i samih podataka, ponuditi održivi model koji će rezultirati kvalitetno prikupljenim podatcima.

Kako je istraživanjem u ovom radu potvrđeno, problem vrste i strukture podataka (a to podrazumijeva i problem postupaka u prikupljanju) koji se prikupljaju za potrebe suda prisutan je desetljećima i ne pokazuje usmjerenost rješavanja. Glavni su generator podataka centri za socijalnu skrb čija su izvješća osobito korisna i ustanovama koje izvršavaju odgojne mjere. Ona su manjkava, nestrukturirana i neujednačena i to ne samo na temelju njihovih usporedbi s obzirom na različite centre za socijalnu skrb, već i unutar istog centra, pa u većini slučajeva stručnim suradnicima pri državnom odvjetništvu i sudu preostaje da ponavljaju postupke njihova prikupljanja ili ih provode jer prethodno nisu dobili relevantne podatke. Tumačenje prikupljenih podataka i dovođenje u vezu obilježja kaznenog djela i maloljetnika s najboljim prijedlogom (ili odlukom suda) osobito je zanemareno područje.

U svjetlu podataka u radu se najpotpunijim pokazalo izvješće jednog centra za socijalnu skrb koji je u dokumentaciji priložio izvješće odjela timske procjene, da je opterećenost centra za socijalnu skrb brojnim drugim poslovima iznimno velika te da oni nemaju specijalizirane jedinice procjene, autorice su mišljenja da bi procedure prikupljanja, strukturiranja i tumačenja podataka trebalo točno propisati i povjeriti točno određenim ustanovama specijaliziranim za te poslove.

Pritom sustav ne treba graditi iz početka budući da postoji osnova. Riječ je o uvodno kratko spomenutim odjelima timske procjene (osnovanih upravo u cilju kvalitetne procjene svih okolnosti i na tome temeljene preporuke odgojne mjere) kojih u Republici Hrvatskoj ima sedam (a koji mogu provesti stacionarne timske procjene), strateški raspoređenih na području cijele zemlje. Iako niti njihove procedure nisu do kraja standardizirane, one čine najbolji potencijal za razvoj dobre prakse.

Naime, mnogo je logike u razmišljanju da uz pribavljanje podataka iz svih mogućih izvora, te uz ambulantni ili stacionarni boravak počinitelja na takvom odjelu, a na temelju standardiziranih procedura, izvješće s prijedlogom najprimjerenije odgojne mjere za potrebe suda, kreiraju upravo ti odjeli. Riječ je o malim interdisciplinarnim timovima koje je lakše okupiti, još lakše educirati te organizirati stručne sastanke radi ujednačavanja i unaprjeđivanja prakse. Redovito korištenje njihovih usluga za potrebe suda bio bi novi model standardiziranoga prikupljanja i tumačenja podataka. Važno je napomenuti da je takav koncept tek djelomično novina, jer se u prošlosti timska procjena počinitelja kaznenih djela češće primjenjivala.

S druge strane, centri za socijalnu skrb su znatno brojniji (ukupno 104 uključujući 
i podružnice) $)^{32}$ i time teritorijalno dostupniji kao servisi državnog odvjetništva i suda, ali su opterećeni nizom drugih poslova i, što je najvažnije, nemaju specijalizirane dijagnostičke jedinice i timove kojima je to primaran i jedini posao.

Iz svega navedenoga proizlazi da je, u svrhu omogućavanja prava svakom maloljetnom počinitelju kaznenog djela biti jednako tretiran i objektivno procijenjen, te da mu se izrekne odgojna mjera u njegovu „najboljem interesu“, potrebno standardizirati ne samo vrste podataka koji se prikupljaju, već i načine tog prikupljanja, odabir relevantnih podataka kojima se argumentiraju rizici, potrebe i kapaciteti maloljetnih počinitelja u skladu s kojima se preporučuje najbolja odgojna mjera. Nažalost, taj se posao ne može obaviti samo oslanjanjem na uvođenje određenih instrumenata (upitnika, skala, testova) iako je njihova primjena korisna i može imati dvije svrhe.

Prva svrha određenog tipa instrumenata/upitnika može biti dobar početni temelj za prikupljanje što šireg spektra obaveznih informacija i ugrubo, bodovanjem, može svrstati konkretnoga maloljetnog počinitelja u skupinu visokog, srednjeg ili niskog rizika te visokih, srednjih ili niskih (tretmanskih) potreba. Neki su od tih upitnika već primijenjeni u hrvatskoj praksi u svrhu prikaza njihove korisnosti. ${ }^{33}$

Druga je svrha različitih instrumenata, uključujući i standardizirane psihološke testove, rasvjetljavanje relevantnih područja u funkcioniranju maloljetnog počinitelja kaznenog djela. Tako, primjerice neki odjeli timske procjene između ostaloga, primjenjuju, tzv. listu zapažanja koja obuhvaća pet područja: odnos prema sebi, odnos prema drugima, odnos prema obrazovanju, interesi, navike, potom skale procjene ometajućih ponašanja, skala ponašanja u ispitnoj situaciji i tako dalje.

Instrumenti neće riješiti pitanje konačne procjene, ali će za sve maloljetne počinitelje osigurati (ako su u svojoj primjeni obvezujući) isti bazen podataka koji se stavlja u kontekst stručne opservacije. Stručnjaci specijalizirani za opservaciju moraju biti u višekratnom ili kontinuiranom osobnom kontaktu s maloljetnikom, (roditeljima, učiteljima i svim relevantnim osobama) trenirani za uočavanje određenih specifičnosti kod maloljetne osobe i za dovođenje u vezu rezultata na instrumentima i rezultata opservacije, nakon čega preporučuju odgovarajuću odgojnu mjeru s naglaskom na tretmanska područja tijekom njezina izvršavanja.

Organizacijski bi (pri postojećem stanju) to značilo da bi operativne i bitne edukacije iz primjene različitih vrsta instrumenata, postupaka stručne opservacije te načina sastavljanja izvješća s preporukom odgojne mjere, trebalo kontinuirano provoditi u 104 organizacijske jedinice centara za socijalnu skrb i osam ustanova

32 Siniša Zrinščak, „Nadležnosti centara za socijalnu skrb u Hrvatskoj“, Revija za socijalnu politiku 9, br. 3 (2002): 383-392.

33 Neven Ricijaš, „Instrumenti procjene djece i adolescenata - mogućnost primjene probacije za maloljetnike“, Ljetopis studijskog centra socijalnog rada 13, br 2 (2006): 271-295; Nivex Koller-Trbović, Branko Nikolić, Velimir Dugandžić, „Procjena čimbenika rizika kod djece i mladih u riziku ili s poremećajima u ponašanju u različitim intervencijskim sustvima: socio ekološki model“, Hrvatska revija za rehabilitacijska istraživanja 45, br. 2(2009): 37-54; Neven Ricijaš, Pripisivanje uzročnosti vlastitog delinkventnog ponašanja mladih, 2009, doktorska disertacija (Zagreb: Pravni fakultet, 2009.), https://bib.irb.hr/datoteka/384000.DOKTORAT_ Neven_Ricijas.pdf. 
socijalne skrbi specijaliziranih za rad s djecom i mladima s poremećajima u ponašanju, koje provode timsku procjenu (u Karlovcu, Osijeku, Puli, Rijeci, Splitu, Zadru i dvije u Zagrebu).

Kontinuirano stoga, jer nije riječ samo o dogovorima o tome što će se i kako od instrumenata primjenjivati, kako opservirati i kako sastaviti izvješće i kvalitetnu preporuku odgojne mjere, već je riječ i o stalnim međusobnim kontaktima radi usklađivanja i ujednačavanja prakse. Povrh toga, instrumenti i metode opservacije stalno se unaprjeđuju, pa dodatna specijalizacija unutar područja timske procjene ne prestaje.

Imajući na umu današnje stanje organizacije centara za socijalnu skrb i njihovo široko područje djelovanja ${ }^{34}$ teško se može očekivati da bi oni mogli razvijati visoko specijalizirane dijagnostičke timove koji bi ponajprije, prikupljali potrebne (unaprijed propisane) podatke, primjenjivali sve dogovorene/propisane instrumente, vršili opservacije te sastavljali kvalitetna izvješća s (relevantnom / argumentiranom) preporukom odgovarajuće odgojne mjere. Zbog dobre teritorijalne pokrivenosti i terenskog rada koji im je imanentan, oni mogu biti dobri generatori (unaprijed propisane vrste) podataka.

S druge strane, potencijal je odjela timske procjene takav da temeljne podatke dobivene od centara za socijalnu skrb postave kao osnovu koju sami mogu dopuniti, a na koju potom nadograđuju primjenu instrumenata i stručnu opservaciju što može rezultirati kvalitetnim izvješćem i preporukom odgojne mjere. Mogući prigovori, koji polaze od toga da postojeći odjeli dobro ne pokrivaju teritorij te da putovanje maloljetnika i njihov boravak u odjelu radi opservacije čini dodatne troškove i drži ih dalje od obitelji i škole, mogu se odbiti. Postojeći odjeli timske procjene mogu se pojačati s nekolicinom dodatnih i strateški rasporediti tako da ujednačenije pokrivaju teritorij. Troškovi putovanja i boravka maloljetnika u odjelu timske procjene vrijedni su kvalitetnog bavljenja njima i njihovom budućnošću, jer materijalna ušteda nije vrijedna truda ukoliko se, kako su naprijed navedene analize pokazale, ne izriču odgovarajuće odgojne mjere. Naime, i tu su se potrošila određena sredstva, a nije ispunjena svrha. Za veliki broj maloljetnika moguća je i ambulantna opservacija. Sličan protuargument može se izreći za prigovor izostanka iz obitelji i škole tijekom stacionarnog dijagnostičkog postupka. Ako se, na razini sustava, želi dobro planirati intervencije za budućnost svakoga maloljetnika, onda kvalitetna opservacija vrijedi (do najviše propisanih 30 dana) izbivanja iz okoline u kojoj živi ${ }^{35}$ Dobrim planiranjem, utreniranošću i uhodanošću dijagnostičkih timova, vrijeme boravka na odjelu timske procjene može se znatnije i skratiti u odnosu na trenutačnu praksu.

Da je ovakav model održiv, govori primjer Japana ${ }^{36}$ koji je po broju stanovnika (oko 130 milijuna) deseta država svijeta. U toj su državi ukupno 52 ustanove specijalizirane za klasifikaciju i procjenu maloljetnih počinitelja kaznenih djela u kojima borave dva tjedna (iznimno, u kompliciranijim slučajevima, dulje i to najviše

34 Zrinščak, Nadležnosti centara za socijalnu skrb u Hrvatskoj, 383-392.

35 Ako je riječ o reopservaciji ili je dijete korisnik usluge smještaja ustanove sustava socijalne skrbi, timska procjena traje 21 dan.

36 Takahashi, Assessment of Juvenile offenders at juvenile Classification Homes in Japan, 151158. 
osam tjedana). Sve jedinice imaju isti pristup prema svakom maloljetniku, koji uključuje: intervju, točno propisane testove koji se smiju primijeniti, opservaciju ponašanja, medicinsku dijagnozu uključujući i psihijatrijsku po potrebi, te pisanje završnog izvješća za sud s preporukom mjere i preporukom vrste tretmana.

\section{ZAKLJUČAK}

Svrha je ovoga rada, nakon istraživačkim postupkom utvrđene i opravdano očekivane (ne)adekvatnosti u procesu prikupljanja podataka kao i samih podataka, koji su sudovima za mladež potrebni kako bi donijeli najbolju odluku pri izricanju odgojne mjere, ponuditi održivi model koji će rezultirati kvalitetnim prikupljenim podatcima. Model je temeljen na suvremenoj filozofiji cjelokupnoga tretmana mladih počinitelja kaznenih djela da su najprimjerenije i najučinkovitije intervencije one koje se oslanjaju na njihove određene potrebe i potencijale. Riječ je o pilot studiji u kojoj se analizira dokumentacija povezana s upućivanjem na izvršavanje jedne odgojne mjere na ograničenom području Republike Hrvatske. Polazna je pretpostavka da se rezultati mogu primijeniti općenito, bez obzira o kojoj je izrečenoj odgojnoj mjeri riječ i na kojem području jer nema osnove za očekivanje da bi kvaliteta dokumentacije bila drukčija s obzirom na to da nema obvezujućih propisa o postupcima prikupljanja i vrsti prikupljenih podataka.

Istraživanje je djelomice bilo ograničeno izborom varijabli u instrumentu za prikupljanje podataka APOM. Iako su one konstruirane u skladu sa zakonskim i stručnim standardima, neke možda nisu bile nužne, a neke je trebalo bolje definirati. No, to će biti zadatak budućeg istraživanja na većem uzorku kako bi se provjerili dobiveni rezultati.

Analizom cjelokupne dokumentacije centara za socijalnu skrb (izvješća) dostavljene ustanovi za izvršavanje odgojne mjere uočava se da ona nije strukturirana, već svako izvješće ima svoj slijed i logiku prikaza podataka. Prosječno je u analiziranim izvješćima navedeno $24 \%$ traženih podataka, a raspon količine dostavljenih podataka u analiziranim izvješćima je, pojedinačno gledano od 7 (5 \%) do 115 (77 \%) traženih podataka (uz standardnu devijaciju 20). Na najbolji pojedinačni rezultat izravno je utjecala činjenica da je uz izvješće priložena i dokumentacija odjela timske procjene. Kad su pojedini centri za socijalnu skrb dostavili više od jednog izvješća, uočava se razlika u njihovoj popunjenosti, primjerice, izvješća iz jednoga centra obuhvatila su od $16,8 \%$ do $63,1 \%$ traženih podataka. To vodi do zaključka da ni pojedini centri za socijalnu skrb nemaju, makar interni, dogovor o načinu sastavljanja izvješća. Ti rezultati potvrđuju dosadašnje spoznaje iz različitih, uvodno navedenih analiza na istu temu od 1976. do danas.

Nadalje, na temelju rezultata istraživanja može se doći do zaključka o velikom preklapanju poslova. No, zajednički nazivnik za izvješća svih stranaka u postupku su izvješća centara za socijalnu skrb koja su, kako rezultati pokazuju, neujednačena, manjkava i katkad iznimno siromašna podatcima.

Usprkos tomu, u velikoj većini slučajeva $(82,4 \%)$ centar za socijalnu skrb, državni odvjetnik i sud za maloljetnike slažu se oko prijedloga i izrečene odgojne 
mjere. Kod neslaganja, državni je odvjetnik taj koji predlaže strožu mjeru od ostalih dionika. Pritom se ne rukovodi težinom djela i prethodnim činjenjem kaznenih djela, već se koristi ili nekim drugim podatcima koji nisu bili na raspolaganju ostalim dionicima, ili pak iste i svima poznate podatke promatra s nekoga drugog stajališta i tumači da bi teža odgojna mjera bila u boljem interesu djeteta.

Imajući na umu rezultat prema kojemu su centri u svojim izvješćima, u prosjeku pružili samo $24 \%$ traženih podataka, postavlja se pitanje na temelju čega je sud djelovao u najboljem interesu djeteta? Jesu li preostali podatci uopće prikupljeni pa nisu dostavljeni ili nisu ni prikupljeni? Stoga se nužno javlja problem dodatnog ili ponovnog prikupljanja potrebnih podataka za potrebe samog tretmana. Hoće li ustanova koja provodi tretman sada poduzeti/ponoviti sve radnje da bi dobila podatke koji su joj mogli/trebali biti dostavljeni jer su ionako prikupljani u svrhu donošenja najbolje odluke suda? Nepreciznost podzakonskih propisa i opisa postupaka rada te neujednačena praksa dovode, dakle, do preklapanja poslova i gubitka vremena, bez ikakvog jamstva da se prema svakom maloljetnom počinitelju kaznenog djela jednako odnosi, odnosno da mu je posvećena jednaka pozornost kao i drugima te da su na isti način ispitane sve zakonom propisane okolnosti.

$\mathrm{Na}$ temelju znanstvenih spoznaja, postojećih stručnih standarda procjene, iskustava u drugim zemljama, ukupnih rezultata ovoga istraživanja i pitanja koje je ono otvorilo, a posebno jednog rezultata prema kojemu je daleko najbolje izvješće centra za socijalnu skrb bilo ono uz koje je bio priložen nalaz i mišljenje timske procjene, autorice ovoga rada predlažu za budućnost održivi model koji će rezultirati kvalitetnim prikupljenim podatcima koji će se istodobno koristiti za potrebe suda i za potrebe tretmana.

Postojeći odjeli timske procjene koji već jesu interdisciplinarno ekipirani i specijalizirani, mogu postati standardni podnositelji nalaza i mišljenja koji uključuju preporuke odgojnih mjera i tretmanskih potreba kako za potrebe suda tako i za potrebe ustanova koje te mjere izvršavaju. Polazne, unaprijed propisane, podatke i dalje im mogu osigurati centri za socijalnu skrb, iako ih spomenuti odjeli mogu i sami prikupiti, a primjenom standardiziranih instrumenata u kombinaciji s ambulantnom ili stacionarnom opservacijom, osigurava se ujednačeno i stručno utemeljeno izvješće za svakoga maloljetnika. Takav se model pokazao kao vrlo učinkovit u Japanu ${ }^{37}$ gdje je rad takvih dijagnostičkih jedinica koordiniran i osigurava kvalitetne podatke.

\section{LITERATURA}

1. Božićević Grbić, Melita i Mirta Kuharić. Zakon o sudovima za mladež- primjena u praksi, Priručnik za polaznike/ice, Izrada obrazovnih materijala. Zagreb: 2017., pristup 20.8.2019. http://pak.hr/cke/obrazovni\%20materijali/Zakon\%20o\%20sudovima\%20 za\%20mlade $\%$ C5\%BE\%20\%E2\%80\%93\%20primjena\%20u\%20praksi.pdf.

2. Carić, Ante i Ivan Kustura. „Kamo ide hrvatsko maloljetničko kazneno zakonodavstvo?“. Zbornik radova Pravnog fakulteta u Splitu 47, br. 3 (2010): 605-620.

37 Takahashi, Assessment of Juvenile offenders at juvenile Classification Homes in Japan, 151158. 
3. Cullen, Francis, T. i Paul Gendreau. „Assessing correctional rehabilitation: Policy, practice, and prospects“. U: Criminal justice: Policies, processes, and decisions of the criminal justice system, ur. J. Horney, str. 109-175. Washington, DC: National Institute of Justice, 2000.

4. Dunkel, Frieder. „Juvenile Justice Systems in Europe - reform developments between justice, welfare and ,new punitivness“. Kriminologijos studios br. 1 (2014). 10.15388/ CrimLithuan.2014.0.3676.

5. Grozdanić, Velinka, Zoran Sršen i Dalida Rittossa. „Kaznena politika općinskih sudova na području Županijskog suda u Rijeci“. Hrvatski ljetopis za kazneno pravo i praksu 11, br. 2 (2004): 567-608.

6. Hall, Margaret. „The Vulnerability Jurisdiction: Equity, parens patriae, and the Inherent Jurisdiction of the Court". Canadian Journal of Comparative and Contemporary Law 2, br. 1 (2016): 186-225.

7. Hirjan, Franjo i Mladen Singer. Komentar Zakona o sudovima za mladež $i$ kaznenih djela na štetu djece i maloljetnika. Zagreb: Nakladni zavod Globus, 2002.

8. Howell, James, C. Guide for implementing the comprehensive strategy for serious, violent, and chronic juvenile offenders. Washington, DC: Office of Juvenile Justice and Delinquency Prevention, 1995.

9. Jung, Sandy i Edward P. Rawana. „Risk and need Assessment of Juvenile Offenders“. Criminal Justice and Behaior 26, br. 1 (1999): 69-89.

10. Koller-Trbović, Nivex, Anja Mirosavljević i Ivana Jeđud Borić. Procjena potreba djece $i$ mladih s problemima u ponašanju- konceptualne i metodičke odrednice. Zagreb: Ured UNICEF-a za Hrvatsku, 2017.

11. Koller-Trbović, Nivex, Branko Nikolić i Velimir Dugandžić. „Procjena čimbenika rizika kod djece i mladih u riziku ili s poremećajima u ponašanju u različitim intervencijskim sustvima: socio-ekološki model“". Hrvatska revija za rehabilitacijska istraživanja 45, br. 2 (2009): 37-54.

12. Koren Mrazović, Marija. „Maloljetnici i mlađi punoljetnici s poremećajima u ponašanju u tretmanu socijalne skrbi u Republici Hrvatskoj“. Kriminologija i socijalna integracija 6, br. 2 (1998): 141-152.

13. Križ, Đurđa. „Kriteriji za odabir odgojnih mjera maloljetnicima u svjetlu primjene Zakona o sudovima za mladež“. Hrvatski ljetopis za kazneno pravo i praksu 6, br. 2 (1999): 366368.

14. Lipsey, Mark, W. „Can rehabilitative programs reduce the recidivism of juvenile offenders? An inquiry into the effectiveness of practical programs". Virginia Journal of Social Policy and Law 6 (1999): 611-641.

15. Lulić Čavar, Gordana. „Neki aspekti evaluacije učinkovitosti tijeka izvršenja odgojne mjere upućivanja u disciplinski centar za maloljetnike". Kriminologija $i$ socijalna integracija 3, br. 1 (1995): 53-70.

16. Mears, Ashley. „Aesthetic Labor for the Sociologies of Work“. Gender, and Beauty, Sociology Compass 8, br. 12 (2014): 1330-1343.

17. Mears, Daniel. „Sentencing Guidelines and the Transformation of Juvenile Justice in the $21^{\text {st }}$ Century“. Journal of Contemporary Justice 18, br. 1 (2002): 6-19.

18. Mikšaj-Todorović, Ljiljana i Mladen Singer. „Obavijest o prethodnim intervencijama društvenih institucija prema malodobnim počiniteljima kaznenih djela i/ili njihovim obiteljima kao kriterij izricanja odgojnih mjera“. Zbornik Pravnog fakulteta Sveučilišta u Rijeci 19, br. 1 (1998): 11-25.

19. New Jersey Code, Purposes, 2009. Pristup 16. siječnja 2020. https://law.justia.com/ codes/new-jersey/2009/title-2a/2a-4a-21

20. Pratt, John. Penal Populism. London, New York: Routledge - Taylor \&Francis Group, 2006. 
21. Radić, Ivana. „Hrvatski sustav maloljetničkih sankcija: trenutačno stanje i prijedlozi za promjenu“. Hrvatski ljetopis za kaznene znanosti i praksu 24, br. 1(2017): 3-115.

22. Ricijaš, Neven. „Instrumenti procjene djece i adolescenata - mogućnost primjene probacije za maloljetnike“. Ljetopis studijskog centra socijalnog rada 13, br 2 (2006): 271-295.

23. Ricijaš, Neven. Pripisivanje uzročnosti vlastitog delinkventnog ponašanja mladih, 2009, doktorska disertacija. Zagreb: Pravni fakultet, 2009., https://bib.irb.hr/datoteka/384000. DOKTORAT_Neven_Ricijas.pdf.

24. Rittossa, Dalida i Melita Božićević Grbić. „Zakon o sudovima za mladež - reformski zahvati i praktične dileme“. Hrvatski ljetopis za kazneno pravo i praksu 19, br. 2 (2012): 615-667.

25. Scholte, Evert, M. „Psychosocial Risk Characteristics of Children in Welfare programmes in Holland". Childhood: A Global Journal of Child Research 5, br. 2 (1998): 185-205.

26. Singer, Mladen, Konstantin Momirović i Vojislav Kovačević. „Kriteriji sudova pri izricanju sankcija maloljetnicima“. Defektologija 12, br. 1-2 (1976): 48-121.

27. Takahashi, Masaru. „Assessment of Juvenile offenders at juvenile Classification Homes in Japan.United nations Asia and Far east Institute for the Prevention of Crime and the Treatment of Offendesr (UNAFEI)“. Resource material 78, (2009): 151-158.

28. Vincent, Gina M., Laura S. Guy i Thomas Grisso. Risk Assessment in Juvenile Justice: A Guidebook for Implementation. Models for Change - systems Reform in Juvenile Justice. MacArthur Fondation. University of Massachusets, 2012.

29. Zagorec, Marina. „Problematika postupanja prema maloljetnim počiniteljima kaznenih djela“. Policija i sigurnost 26, br. 4 (2017): 283-301.

30. Zakon o sudovima za mladež, Narodne novine, br. 84/11., 143/12., 56/15., 126/19.

31. Zermatten, Jean. „The best Interests of the Child. Literal Analysis, Function and Implementation, Institut International des Droits de lenfant". Working Report, 2009.

32. Zrinščak, Siniša. „Nadležnosti centara za socijalnu skrb u Hrvatskoj“. Revija za socijalnu politiku 9, br. 3 (2002): 383-392. 


\section{Ljiljana Mikšaj - Todorović* \\ Maja Vučić Blažić**}

\section{Summary \\ COURT DECISION CRITERIA ON CORRECTIONAL MEASURES}

Starting point of this paper is the contemporary philosophy of the treatment of young offenders, which recognizes that the most appropriate and effective intervention is one that relies on their specific needs and potentials. In order for the juvenile court to be able to make the best decision on the correctional measure, it needs relevant information.

The paper analyzes the reports of social welfare centres in terms of their informative nature as well as the overlap of the correctional measures proposals given by parties to court proceedings with court decisions. As expected, the reports are unstructured, uneven and incomplete. Of the 149 expected data, only a quarter was delivered to the courts on average. Nevertheless, the overlap between the proposals of correctional measures by different parties and the court's decisions is very high.

The purpose of this paper was to offer a sustainable model that will result in quality data collected, based on the results. The model is described in the paper.

Keywords: juveniles; criminal offenses; criteria; correctional measures; reports.

\section{KRITERIEN FÜR VERHÄNGUNG VON ERZIEHUNGSMASSNAHMEN}

Laut modernster Philosophie der Behandlung von jungen Straftätern sei die passendste und wirksamste Intervention jene, die spezifische Bedarfe und Potenziale der Straftäter berücksichtigt. Damit ein Jugendgericht die bestmögliche Entscheidung über passende Erziehungsmaßnahme treffen könnte, gebraucht es ausschlaggebende Auskünfte. Ausgehend von diesem Hintergrund befasst sich der vorliegende Beitrag mit von den Jugendämtern erfassten Berichten. Letztere werden im Hinblick auf ihre

* Ljiljana Mikšaj - Todorović, Ph.D., Full Professor, Faculty of Education and Rehabilitation Sciences University of Zagreb, Department of Criminology; ljiljana.miksaj-todorovic@erf.hr.

** Maja Vučić Blažić, Professor of Social Pedagogy, Center for Community Service, Zagreb-

Dugave; vucicblazicmaja@gmail.com. 
Auskünfte und Übereinstimmung der vorgeschlagenen Erziehungsmaßnahmen der Verfahrensparteien und Gerichtsbeschlüsse überprüft. Erwartungsgemäß sind die Berichte weder strukturiert noch vollständig, und weichen voneinander aus. Von 149 voraussichtlichen Auskünften sei durchschnittlich ein Viertel den Gerichten vorgelegt worden. Nichtdestotrotz stimmen die vorgeschlagenen Erziehungsmaßnahmen mit denen, die aus Gerichtsbeschlüssen ergehen stark überein. Ausgehend von der Analyse der erwartenden (nicht) adäquaten Verfahren der Auskunftserteilung und mangelhaften Auskünfte für den Bedarf der Gerichte wird ein durchführbares Modell der Auskunftserteilung vorgeschlagen. Wie im Beitrag dargestellt wird, würde dieses Modell ermöglichen hochwertige ausschlaggebende Auskünfte zu erteilen.

Schlüsselwörter: Minderjährige; Straftaten; Kriterien; Erziehungsmaßnahmen; Berichte.

\section{Riassunto}

\section{CRITERI PER L'IMPOSIZIONE DI MISURE EDUCATIVE}

In questo lavoro si parte dalla filosofia contemporanea del trattamento dei giovani che commettano reato. Tale filosofia si fonda sulla cognizione che l'intervento più adeguato ed efficace sia quello che poggia sulle loro specifiche esigenze e sui loro potenziali. Affinché la corte possa giungere alla decisione migliore sulla misura educativa, essa necessita dei dati rilevanti.

Nel lavoro sono analizzate le relazioni dei centri di assistenza sociale nel senso della loro informatività, come anche della sovrapposizione delle proposte delle parti sulle misure educative con le decisioni della corte. In linea con le aspettative emerge come le relazioni non siano strutturate, non siano uniformi e siano incomplete. Dei 149 dati aspettati, alle corti di media ne perviene appena un quarto. Nonostante questo, le sovrapposizioni delle misure educative proposte da parte dei diversi portatori d'interesse con le decisioni della corte sono molto alte.

L'obiettivo di questo lavoro è, dopo avere individuato nel corso della ricerca le (in)adeguatezze, a ragione prevedibili, nel processo di rilevamento dei dati, come pure i dati stessi per le finalità della corte, offrire un modello sostenibile che risulterà in un rilevamento dei dati di qualità. Il modello è descritto nel lavoro.

Parole chiave: minorenni; reati; criteri; misure educative; relazioni. 
